National Bureau of Standards

U. S. DEPARTMENT OF COMMERCE JESSE H. JONES, Secretary

NATIONAL BUREAU OF STANDARDS

LYMAN J, BRIGGS, DIrector

\title{
SOLID-FUEL-BURNING FORCED-AIR FURNACES
}

\section{COMMERCIAL STANDARD CS109-44}

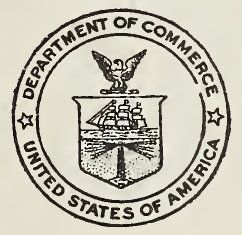

A RECORDED VOLUNTARY STANDARD

OF THE TRADE

UN ITED STATES

GOVERTMENT PRINTING OFFICE

WASHINGTON : 1944

For sale by the Superintendent of Documents, U. S. Government Printing office, Washington 25, D. C...--Price 10 cents 


\section{P R O M U L G A T I O N}

of

\section{COMMERCIAL STANDARD CS109-44}

for

\section{SOLID-FUEL-BURNING FORCED-AIR FURNACES}

Pursuant to a request dated April 20, 1942, from the Federal Housing Administration, there was developed with the aid of interested agencies and 1 aboratories, including the National Warm Air Heating \& Air Conditioning Association and the Anthracite Industries Laboratory, a proposed commercial standard for coal-burning furnaces.

A draft was circulated November 11 and 12, 1942, to leading distributors, testing laboratories, manufacturers, and users for comment. Following adjustment on February 22 and 23, 1943, in the light of that comment and after special consideration by the NWAHACA, a revised draft of the proposed commercial standard was circulated on August 16, 1943, to the entire trade for written acceptance.

Those concerned have since accepted and approved the standard as shown herein for promulgation by the United States Department of Commerce, through the National Bureau of Standards.

The standard is effective for new production from March 10, 1944.

Promulgation recommended.

I. J. Fairchild, Chief, Division of Trade Standards.

Promulgated.

Lyman J. Briggs, Director, National Bureau of Standards.

Promulgation approved.

Jesse H. Jones, Secretary of Commerce. 


\section{SOLID-FUEL-BURNING FORCED-AIR FURNACES}

\section{COMMERCIAL STANDARD CS109-44}

\section{PURPOSE}

1.0. This standard is provided as a basis for guaranteeing the construction and performance of solid-fuel-burning forcedair furnaces for the guidance of manufacturers, testing $1 \mathrm{ab}-$ oratories, distributors, installers, contractors, and purchasers.

\section{SCOPE}

1.1. This standard covers surface-fired and magazine-feed, solid-fuel-burning warm-air furnaces with forced-air circulation in sizes up to $80,000-B$ tu output, when using chestnutsize anthracite as a test fuel, and is composed of the following sections:

2. General requirements...

3. Construction requirements. 3

4. Performance requirements under test

5. Test code._.

6. Data and report sheet. 12

7. Informative 1 abeling 16 Appendix I-method of interpolating test results_._. Appendix II-graphic method of determining flue gas loss_-_- 28 Appendix III-suggested form of $10 \mathrm{~g}$ data sheets__. 30

8. Effective date_._. 31

9. Standing committee. 31

10. History of project. 32

11. Acceptors. 35

\section{DEF INITIONS}

1.20. Furnace.-A warm-air furnace is a device for the transfer of heat generated by the combustion of fuel within the device to air that flows between the combustion chamber and an outer enclosing jacket to pipes or ducts that carry the heated air to the desired locations.

1.21. Gravity furnace.-A gravity furnace is defined as one which depends primarily upon the difference between the 
weight of the heated air and the return cold air to produce circulation.

1.22. Forced-air furnace.-Forced-air furnaces are defined as those which depend upon power-driven fans or blowers to produce circulation of the heated air.

1.30. Standard air is air weighing $0.075 \mathrm{lb} / \mathrm{cu} \mathrm{ft}$. (This weight corresponds to dry air at $70^{\circ} \mathrm{F}$ or air with 50-percent relative humidity at a dry-bulb temperature of $68^{\circ} \mathrm{F}$.when the barometric pressure is 29.92 in. mercury•) Specific heat is taken as 0.243 .

1.31. Air delivery (cfm) is the quantity of standard air, in cubic feet per minute, discharging from the bonnet.

1.40. Heat input is the total gross heating value of the coal supplied to the furnace, expressed in $\mathrm{Btu} / \mathrm{hr}$.

1.50. Bonnet output is the heat delivered at the bonnet of the heater, expressed in $B t u / h r$.

1.60. Bonnet efficiency is the ratio of the bonnet output to the heat input expressed in percentage.

1.70. Stack loss is the percentage of the heat value of the fuel carried in the flue gases in the flue pipe, as arrived at by the graphic method, figure 4, and explained in appendix II. It includes the sensible heat in the dry gases, the heat of the steam in the flue gases, and the superheat of the moisture in the combustion air.

1.80. Maximum rating is the average bonnet output developed by the furnace during the test cysle when complying with the provisions set forth under paragraphs 4.10 to 4.20 , inclusive.

1.81. Minimum rating of a furnace is defined as three times the output as measured in the banking test described in paragraph 5.71 .

1.82. The range af rating of a furnace is that range of output between the maximum rating and the minimum rating. A given furnace may be used to supply any house with a design heat loss falling within that range.

\section{GENERAL REQUIREMENTS}

2.0. Dependability. - The furnace shall be capable of functioning satisfactorily when installed and adjusted in accordance with the manufacturer's instructions.

2.1. Durability. - The design and construction of the furnace shall be such as to insure its durability in service as outlined in section 3 . The outer casing or jacket shall be constructed of steel or other suitable material and of such design that it is not readily damaged or dented in use.

2.2. Efficiency. - The furnace shall be capable of meeting the minimum efficiency requirements as outlined in paragraph 4.10 . 
2.3. Operating instructions.-Each furnace shall be accompanied by a complete set of instructions covering essential points with respect to installation, operation with the various fuels and general upkeep.

2.4. Draft regulator.-The furnace shall be equipped with an automatic draft regulator so located and permanently set as to limit the burning rate to the maximum rated output of the furnace. The draft regulator, if of the barometric type, shall be set by the installer according to the furnace manufacturer's instructions for the fuel used, so as to limit the burning rate to the maximum rated output of the furnace.

2.5. Fan switch.-An adjustable, bonnet-installed, fan switch having an approximate range of $70^{\circ}$ to $200^{\circ} \mathrm{F}$ shall be supplied with each furnace.

2.6. Filters.-If filters are supplied, they should be 1 in. or more in thickness and of one of the following sizes: 16 by 20,20 by 20,16 by 25 , or 20 by 25 in.

\section{CONSTRUCTION REQUIREMENTS}

3.0. Combustion chamber. - If of steel, the combustion chamber shall be constructed of not lighter than No. 10 gage.

3.1. Flue collar shall be constructed of cast iron, or of sheet steel of suitable thickness, but not less than No. 16 gage, and shall be rigidly attached at the flue outlet of the furnace. It shall afford convenient suitable means for attaching the flue pipe securely to the furnace.

3.2. Radiators or economizers when used shall be constructed of not lighter than No. 16 gage steel or other suitable material, and the construction shall be such as to insure strength, rigidity, and durability. All horizontal surfaces in radiators shall have access for cleaning without removing casing panels.

3.3. Doors.-Joints between all doors and access opening covers and their frames shall be fitted so that a piece of paper of the width and thickness of United States paper currency, placed at any point around the perimeter of the opening, cannot be withdrawn when the door is closed. The fire door of surface-fired furnaces shall be protected from direct radiation by means of a suitable liner.

3.31. Handles.-All handles for firing doors and dampers shall be so designed as to minimize the danger of burns from personal contact.

3.4. Grates.-Grates shall be of such materials and construction as to provide a reasonable life under normal operating conditions and shall be of the shaking type and may be of the shaking and dumping type.

3.5. Finish.-Outside surfaces of furnace casings, grilles, and accessories shall be adequately protected against rust 
or corrosion and against damage during manufacture, shipment, and reasonable conditions of storage.

3.6. Sheet-steel gages.-All sheet-steel gages specified in this standard shall be interpreted as follows:

\begin{tabular}{|c|c|}
\hline $\begin{array}{c}\text { Manufacturers' standard } \\
\text { practice gage numbers }\end{array}$ & $\begin{array}{l}\text { Thickness (inch) plus } \\
\text { or minus mill } \\
\text { tolerance }\end{array}$ \\
\hline 10 & $\begin{array}{r}0.1345 \\
.1046 \\
.0747 \\
.0598\end{array}$ \\
\hline
\end{tabular}

3.7. Electrical equipment.-All electrical parts supplied by the furnace manufacturer, including electric controls and electric motors, shall meet such safety requirements of the Underwriters' Laboratories, Inc. as are applicable to such equipment.

3.71. Motor.-The motor shall conform to NEMA specifications for general purpose motors, and its name-plate rating shall equal or exceed the load occurring when the fan is operated in place in the furnace with all the duct work ard air filters removed. General purpose motors with a service factor as defined by NEMA standards shall be considered as meeting the above requirements when provided with suitable integral overtemperature protection.

3.8. Air filters when used must be so located that no point on the filter will reach a temperature in excess of $90^{\circ} \mathrm{F}$ above room temperature when the furnace is being operated at maximum output with the forced-air equipment either operating or not operating. Average velocity through filters shall not exceed $300 \mathrm{fpm}$ on nominal external dimensions of the filter, during maximum rating test.

\section{PERFORMANCE REQUIREMENTS UNDER TEST}

4.00. A stock model of the furnace as offered for general sale shall, when tested as described under section 5 , meet the following performance requirements:

4.10. Efficiency.-The average bonnet efficiency from three consecutive test cycles shall be at least 55 percent for forced-air circulation furnaces.

4.11. Stack temperature.-The flue-gas temperature, measured as hereinafter specified, shall not exceed $830^{\circ} \mathrm{F}$ above laboratory temperature.

4.12. Draft.-The draft used, measured as hereinafter specified, shall not exceed 0.06 in. water gage.

4.13. Attention period.-The period between attentions shall be at least 8 hours for surface-fired and 12 hours for magazine-feed furnaces. Attention shall be considered 
firing, poking, or shaking grates. Adjustment of dampers at any time is permissible attention.

4.14. Heat-exchanger-surface temperature.-The temperature of the metal serving as heat-exchanger surface shall not exceed that of the inlet air temperature by more than $930^{\circ} \mathrm{F}$ as measured by the thermocouples. The average for the entire test as indicated by thermocouple readings taken at the selected spots on the heat-exchanger surface shall not exceed $830^{\circ} \mathrm{F}$ above inlet air temperature.

4.15. Surface temperature.-The surface temperature of the jacket when operating at maximum rating shall not exceed $230^{\circ} \mathrm{F}$ above laboratory temperature except at points above the firing door or within 6 in. of the sides of the door frame or within 6 in. of the flue pipe.

4.16. Bonnet pressure.-The pressure of delivered air in the bonnet shall be maintained at 0.20 in. water gage.

4.17. Air-temperature rise. -With a bonnet pressure of 0.20 in. water gage, the blower shall deliver a flow of such volume that the average air-temperature rise shall not exceed $100^{\circ} \mathrm{F}$ or be less than $70^{\circ} \mathrm{F}$.

4.18. Laboratory temperature.-The laboratory temperature shall be taken as that of the inlet air. ( $\left.\mathrm{T}_{2}, \mathrm{fig} .1\right)$

4.19. Fan operation. $\rightarrow$ The fan shall be operated continuously during all tests, except as otherwise specified.

4.20. Air filters.-Air filters shall not be in place, except during air-filter temperature tests.

4.30. Banking.-With the furnace regulated in accordance with manufacturer's instructions for banking, and with the coaling doors closed, the furnace shall maintain a fire which will produce not more than 25 percent of the maximum output rating on the basis of fuel consumption, for a minimum of 12 hr for surface-fired furnaces and $24 \mathrm{hr}$ for magazine-feed furnaces.

4.40. Gassing.-With the coaling doors closed and the furnace otherwise in accordance with the manufacturer's instructions, there shall be no noticeable gassing from the furnace at any time during the firing and banking cycle.

\section{TEST CODE}

5.0. The Btu input, output, efficiency, and cfm air delivery shall be determined in accordance with the following method, or its equivalent as approved by the standing committee. A list of data to be recorded and methods of calculation are shown in paragraphs 6.0 and 6.1 .

5.10. Furnace and filter.-The furnace shall be erected in accordance with the manufacturer's instructions, omitting air filters, if any. Humidifiers, if provided, shall be in place but left dry. The furnace shall be provided with inlet 
and outlet ducts, as shown in figure 1. Connections shall be provided for measuring the static pressure at the points at which the outlet duct is connected to the furnace. The instruments for testing draft and static pressure, measuring stack temperature and temperatures of inlet and outlet air, and for sampling flue gas shall be installed as shown in figures $1,1 \mathrm{~A}, 1 \mathrm{~B}, 5,6$, and 7 .

5.11. Source of draft.- Means shall be provided capable of producing a draft of 0.06 in. of water at the smoke outlet with the furnace operating at its rated capacity.

5.20. Thermocouples.-Thermocouples of not larger than No. 20 AWG wire with a maximum diameter of twisted junction of 0.07 in., as shown in figure 7 , shall be used for measurement of the flue-gas and heat-exchanger-surface temperatures. For measurement of heat-exchanger-surface temperature, arrange the temperature-sensitive end of the thermocouple, so that the junction and at least 1 in. of the wires back from the junction are in contact with the hot surface of the heater and secure them with the minimum amount of furnace cement required for mechanical support. The furnace cement adheres to the metal better if applied when the furnace is cold. It may be hardened quickly at the time of application by a gas flame or blow torch.

5.201. Thermocouple grid. - The thermocouple grid for measuring outlet air temperature is constructed as shown in figure $1 B$ and located as indicated in figure 1. The arrangement shown provides one thermocouple junction for each one-twelfth of the air flow meter throat area, and makes available a mean temperature value correctly weighted as to area and volume, provided the velocity is uniform at all poin,s in the throat section.

5.202. Thermocouple wire.-The materials for thermocouple wires shown on figures $1 \mathrm{~B}$ and 7 were selected as being generally the most suitable for the purpose. Laboratories using thermocouples of junction materials other than those shown in figures $1 \mathrm{~B}$ and 7 shall submit, with each test report, a statement that the thermocouples used have been calibrated through the range of temperatures involved.

5.21. Damper or draft regulator. - If the furnace is equipped with dampers in such position as to interfere with the flue-gas sampling or temperature-measuring arrangement described above, such dampers shall be either removed or sealed during the tests. See also paragraph 2.4 and figure 5 .

5.22. Weighing scales. - Scales reading to $0.51 \mathrm{~b}$ shall be provided for weighing fuel.

5.23. Draft gages:- Measurements of the chimney draft shall be made with gages graduated in divisions representing 0.01 in. of water. Gages shall be checked for zero readings at the beginning and the end of each test. A draft gage with 
an accuracy of plus or minus 0.005 in. of water column shall be used.

5.24. Pressure gage. - An inclined draft gage shall be provided and arranged as shown in figure 1 to determine the pressure loss in the connected duct system external to the casing. The static-pressure connections shall consist of a 1/4-in.-diameter nipple soldered to the surface of the duct and centered over a hole one-sixteenth of an inch in diameter drilled through the sheet-metal duct. The inner surface of the duct adjacent to the hole shall be free from burrs and irregularities.

5.25. Air-flow meter. - Arrangements shall be made for measuring the air flow through the unit under test as shown in figure 1. A general calibration curve for the 9-in. measuring section is shown in figures $2 \mathrm{~A}$ and $2 \mathrm{~B}$, for the case in which the Pitot tube is located in the center position. The gage used in connection with the Pitot tube shall have an accuracy of \pm 0.002 in. of water column.

5.26. Bonnet output. - The bonnet output shall be computed from the quantity of air delivered, as determined in 5.25, and its observed temperature rise. (See figs. 2, 2A, $2 \mathrm{~B}$, and 3 ; also Report of Data and Method of Calculation, par. 6.0 and 6.1.$)$

5.27. Fan measurements. - A wattmeter shall be placed in the electric circuit of the fan motor to measure the power consumption. A determination shall be made of the speed of the fan under test conditions.

5.28. Temperature measurement. - Accurately calibrated instruments shall be provided for all temperature measurements. A mercury thermometer may be used at the air inlet, but a thermocouple is preferable. The instruments shall be shielded against radiation from the firepot and radiator (if installed) of the furnace.

5.29. Flue-gas analysis. - The flue-gas sample for analysis shall be taken as indicated in figures 5 and 6 and measured by an orsat or equivalent gas analyzer equipped for determination of $\mathrm{CO}_{2}, \mathrm{O}_{2}$, and $\mathrm{CO}$.

5.30. Fuel for test. - The fuel used for these tests shall be anthracite with the following characteristics: Volatile matter 4 to 6 percent; ash content not to exceed 12 percent; heating value (dry basis) 13,000 Btu/lb or above; size, chestnut, according to Standard Anthracite Sizing Specifications adopted by the Anthracite Committee of the Production Control Plan for the Anthracite Industry, Harrisburg, Pa., effective December 15, 1941. (See p. 12, 7th edition, Mac's Directory and Handhook of Anthracite, published by National Coal Publications. Mimeographed copies of the sizing specifications may be obtained on request from the Anthracite Committee, State Street Building, Harrisburg, $\mathrm{Pa}$. ) 
5.31. Fuel sampling.-A gross sample of fuel shall be collected, crushed, mixed, and divided until reduced to a laboratory sample. This sample shall then be placed in a sealed container for transportation to the laboratory. The sampling procedure shall be strictly in accordance with Tentative Method of Sampling Coals Classed According to Ash Content, American Society for Testing Materials Designation D 492-40 T, or later revision. (Adherence to ASTM procedure is necessary to obtain a sample which accurately represents the coal.)

5.32. Lot sampling. - When a number of tests are to be conducted with the same lot of fuel, it shall be permissible to sample the entire lot for proximate analysis and calorific value as specified in ASTM Designation D 492-40 T, or later revision. When this method is used, samples shall be collected on arrival and the coal stored in a dry place until used.

5.40. Observation test. - In order to determine the proper location of thermocouples used to register maximum temperature of heat-exchanger surface, a separate observation test shall be made as follows: (a) The furnace shall be examined to determine whether all parts of the heat-exchanger surface will be visible through air intake or other openings while the furnace is under test. If such is not the case, suitable provision shall be made for observing directly all portions of the heat-exchanger surface or for sampling temperatures upon it. by means of a thermocouple. Observations may be made or temperatures sampled through small holes drilled in the furnace jacket. These holes shall be tightly closed with wooden plugs or by other suitable means except when used, one at a time, for observation or temperature measurement. Plugs should not protrude into the warm-air spaces more than onequarter of an inch. (b) Fire shall be kindled and test fuel fired with amount sufficient to fill the firepot to the level of the firing door, or according to the manufacturer's instructions for both surface-fired and magazine-feed units. (c) With warm-air circulating fan operating at specified bonnet pressure, the drart shall be so adjusted, by means other than the automatic draft regulator and not to exceed 0.06 in. water gage, as to $r$ aise the flue-gas temperature $830^{\circ} \mathrm{F}$ above laboratory temperature, if attainable. If this temperature is not attainable, test shall be run with a stack draft of 0.06 in. water gage, except that in no case shall the test be run with a value of draft such as to cause severe overheating of any part of the heat-exchanger surface. $0 b-$ servations and notations shall be made of location and sequence of appearance of visibly glowing areas of heat-exchanger surfaces. If no glowing spots are observed, areas of maximum temperature shall be located with a contact thermocouple. (d) At the end of $4 \mathrm{hr}$, grates shall be dumped and all ash and 
unburnea fuel removed, the furnace allowed to cool, and thermocouples attached to the heat-exchanger surface in three separate places, as indicated by tre test, preference being given to points first attaining high temperatures.

5.41. Preliminary cycle.-(a) A preliminary cycle, with a full charge of fuel as described below, shall be run to determine. whather the temperature of the heat-exchanger surface (par. 4.14), of the jacket surface (par.4.15), or of the stack is the limiting temperature. Fire shall be kindled with a weighed quantity of wood or charcoal on whick shall be fired a weighed amount of test fuel filling the fire pot to the level of the firing door, or according to the manufacturer's instructions for both surface-fired units and magazine-feed units. No further attention shall be given the fuel bed. (b) The draft shall be so adjusted by means other than the automatic draft regulator and not to exceed 0.06 in. water gage, as to raise the flue-gas temperature as quickly as possible to $830^{\circ} \mathrm{F}$ above laboratory temperature, if attainable, or to the maximum temperature permitting compliance with paragraphs 4.14 and 4.15, whichever is the lower, and shall then be so adjusted as to maintain this flue-gas temperature. (c) If, with 0.06-in. draft, the flue-gas temperature fails to reach $830^{\circ} \mathrm{F}$ above laboratory temperature, or such temperature as would permit compliance with the limitations specified in paragraphs 4.14 and 4.15 , the test shall be run at the highest flue-gas temperature attainable with 0.06 -in. draft. (d) If the preliminary cycle reveals that the automatic draft regulator is not set as to limit the burning rate to the maximum rated output, it shall be so readjusted, set, and left without change for the remaining test cycles.

5.42. Flue-gas test temperature. -The maximum flue-gas temperature arrived at under the conditions specified for the preliminary cycle, paragraph 5.41, (b) or (c), shall be the maximum temperature used to control the three subsequent test cycles and shall be called the flue-gas test temperature.

5.43. End of cycle.- The preliminary cycle shall be considered to have ended when the difference between the fluegas temperature and the laboratory temperature drops to 75 percent of the difference between the flue-gas test temperature and the laboratory temperature, or in the case of magazinefeed furnaces, at any time after a 12-hr attention period, according to the instructions of the manufacturer, provided that the first temperature difference mentioned above has not dropped below 75 percent of the second temperature difference. For a surface-fired furnace, if the preliminary cycle test shows that the fuel hed at the cycle end point, determined by the temperature difference method described above, will not kindle the new charge, the cycle shall be considered to have ended at any time after the 8-hr attention interval, according to the instructions of the manufacturer. 
5.44. If there is no glow in the ash pit, the grates shall be shaken until a glow appears in the ash pit and the ashes removed. The furnace shall then be filled with a weighed amount of test fuel to the level of the firing door, or according to the manufacturer's instructions.

5.50. Test cycles.

5.51. Three consecutive test cycles shall then be run with the automatic draft-regulator setting and within the limit of the flue-gas test temperature obtained from the preliminary cycle, paragraphs 5.41 and 5.42 .

5.52. The end of each cycle shall be determined as described in paragraph 5.43. The grates shall then be shaken until a glow appears in the ashpit and the ashes removed. The furnace shall then be filled with a weighed amount of test fuel to the level of the firing door, or according to the manufacturer's instructions.

5.53. If the conditions specified in paragraphs 4.11 to 4.15, inclusive, have been met, no further tests except banking and pickup (par. 4.30,5.71, and 5.72) and temperature of air filter (par, 3.8 and 5.80) will be required. If the specified conditions have not been met, the test cycles shall be repeated at one or more lower stack temperatures until the requirements have been met. Results may then be interpolated as illustrated in appendix I.

5.60. Frequency of observations.

5.61. Observations of stack drafts and temperatures and of the temperature and velocity of the heated air shall be made at regular intervals of 20 min during test cycles other than the banking test. Test recordings shall start 10 min after firing is completed.

5.62. Instantaneous samples of flue gas shall be taken at intervals not to exceed $20 \mathrm{~min}$ or, as an alternate, the flue gas may be continuously sampled and collected in bottles for analysis.

5.70. Banking test.

5.71. The banking test shall immediately follow a test cycle. The primary air damper shall be closed and the draft reduced to a minimum consistent with the maintenance of combustion by the means provided with the furnace by the manufacturer. The fan shall be operated by the automatic fan switch, set according to the manufacturer's recommendations. Under those conditions the furnace shall operate as described in paragraph 4.30. During the banking test, only weight of fuel charged, and time of start and finish, need be recorded.

5.72. At the end of the banking period, the grates shall be shaken until a glow appears in the ashpit, a weighed fresh charge of fuel shall be added to the level of the bottom of the firing door or according to the manufacturer's instructions; The primary air damper shall be opened and the draft increased to $0.06 \mathrm{in}$. water gage, or to the value arrived at 
during the preliminary cycle, paragraph 5.41 (b) and (c). The stack temperature shall rise to $830^{\circ} \mathrm{F}$ above laboratory temperature or to the flue-gas test temperature in not more than 1 hour.

5.80. Air-filter temperature test.- Where provision is made in the furnace for the use of an air filter, a stock filter shall. be provided by the furnace manufacturer for use in the air-filter temperature test. A thermocouple shall be attached to the center of that face of the filter exposed to the more severe direct radiation, and when, at the end of the test for pickup after banking, the flue gas has attained the flue-gas test temperature, the filter shall be inserted. With the fan operating, air filter temperatures shall be recorded at 5-min intervals until constant temperature is attained, as indicated by three consecutive readings. The fan shall then be turned off and readings to constant temperature taken as before.

5.90. Maximum rating.- The maximum rating of the furnace, to meet the requirements of paragraphs 4.10 to 4.20 , inclusive, shall be determined as described in paragraphs 5.51 to 5.53 , inclusive.

5.91. Minimum rating. - The minimum rating need not be established by test but shall be computed on the following assumptions :

(a) A fuel-burning rate of not less than three times that observed during the banking test.

(b) An efficiency equal to that observed during the test for maximum rating. 


\section{0. SOLID-FUEL-BURNING FORCED-AIR FURNACES \\ DATA AND REPORT SHEET}

Complete information is required, for purposes of checking the data and for permanent records. Fill in all spaces. If additional space is required, use separate pages and attach to the data sheets. Note.- Suggested 1 og data sheets for recording running data are contained in appendix III.

\section{General information:}

1. Manufacture $r^{\prime} s$ name

2. Address

3. Laboratory test No.

4. Date of test 5. Test conducted by

Furnace data:

6. Identification

a. Steel or cast iron

b. Type

c. Catalog designation

7. Metal thickness

a. Combustion chamber: head.

b. Flue collar

c. Radiator

d. Casing

8. Casing

a. Shape: Round Elliptical

b. Size:

Plan view dimensions...in.; Height_.._in.

9. A1r inlet to casing

a. Top, side, or bottom

b. Dimensions: Diam_.....1n.; Width......in.; Leng th...... in.

10. Air outlet from casing_-a. Dimensions: Diam__._-in.; Width___._in.; Leng th...... in.

11. Air filters specified, --a. Make but not installed in capacity tests.

b. Number used. .

12. Blowe r

c. Size: Width........1n.; Length_._._._. in.; Thick. ........ in.

a. Make

b. Wheel size: Width....in.; 0.D. .......1n.

c. Outlet: Diam_.......in.; Helght_......in.; Width.....-1n.

d. Pulley size.......... in.

e. Fan rating for $3 / 8$ in. s.p.......... c fm. - - -....... bhp.

13. Blower motor

a. Make Catalog No.

b. Type -......

c. Horsepower rating

d. Pulley size (nominal) .....-in.

Fuel data:

14. Coal used

a. Kind b. Size

15. Proximate analysis (as recelved).

a. Volatile matter

b. Fixed carbon.

c. Moisture

.

d. Ash

$-\%$

Ash. ...................

e. Calorific value ....Btu/1b 
16. Analysis (as fired,

-a. Moisture

if stored exposed

b. Ash

to weather).

Limiting temperatures derived from preliminary cycle:

17. Temperature rise of _._._Maximum__.

heat-exchanger surface. Average -

18. Temperature rise of

jacket _._.

19. Flue-gas test temperature

${ }^{\circ} \mathrm{F}$

\section{Duration of test: \\ 20. Time of firing of coal-..- \\ 21. Time at end of cycles. \\ 22. Duration of cycles, -...-hr \\ Pruel input: \\ Kindling, $-1 b$ \\ Intial \\ charge, ...-...-1b_...-.}

23. Fuel fired at end of

test cycles $-1 b$
Third cycle

Total for $11 \mathrm{~m}$

irst

Second cycle

- - - -

- - - - - - - -

-
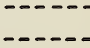

24. Rate of fuel

consumption_.......-1b/hr

25. Calorific value of

coal (as fired)

26. Rate of heat input_-Btu/hr

Combustion data (average for each cycle):

27. Draft at smoke out let_._._._.-_in. water

28. Flue-gas temperature rise above laboratory temperature:
a. Maximum -
b. Average

-....-
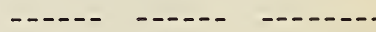

29. Temperature of

combustion alr

30. Flue gas analysis:
a. $\mathrm{CO}_{2}$
b. $\mathrm{O}_{2}$
c. $\mathrm{CO}$

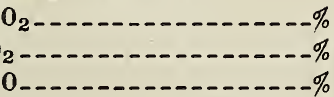

Air circulation and blower data:

31. Barometric pressure, ave rage._._.......in. Hg

32. Air temp at outlet, ave rage, $\left(\mathrm{T}_{1}\right) \ldots$

33. Air temp at inlet, average, $\left(\mathrm{T}_{2}\right)$

34. Temperature rise, average, $\left(\mathrm{T}_{1}-\mathrm{T}_{2}\right)$ OF 
35. Density of air at outlet, average........-.1b/cu ft

36. Velocity pressure at

flow meter, average _....... In. water

37. Volume of air at outlet_._._._._._._._cfm

38. Welight of circulated air, average......-1b/min

39. Static pressure at outlet duct, average_..-in.water

40. Blower speed_._._-_._-rpm

41. Electric input to blower motor-_._-_._-_..-watts

42. Air delivery (standard cond. ) -............... cfm

Capacities and efficiencies:

43. Bonnet output (maximum rating) -.........Btu/hr

44. Stack loss (from curve) $--\%$

45. Radiation and unaccountedfor loss_-_-_._-_-_-_. $\%$

46. Bonnet efficiency

(direct) -............. $\%$

47. Indirect efficiency

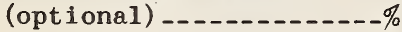

Banking test:

48. Weight of coal charged at end of banking

test_.................. lb

49. Length of banking test_-hr

50. Rate of fuel

consumption_..--..--1b/hr

51. Ratio of banking rate

to test rate.

52. Minimum rating.

Btu/hr

Pickup test:

53. Time for pickup to

flue-gas test

temperature _..........min

54. Air filter temperature

a. Actual_......... ${ }^{\circ} \mathrm{F}$

b. Rise above laboratory temp_-...-...... ${ }^{\circ} \mathrm{F}$

55. Air velocity through

filter._._._._._. $\mathrm{ft} / \mathrm{min}$ average

6.1 Method of calculation:

Item $24=$ Rate of fuel consumption, $1 \mathrm{~b} / \mathrm{hr}$

$$
=\frac{\text { Fuel fired at end of test cycle, } 1 \mathrm{~b}}{\text { Total duration of test cycle, hr }}=\frac{\text { Item } 23}{\text { Item } 22} \text {. }
$$

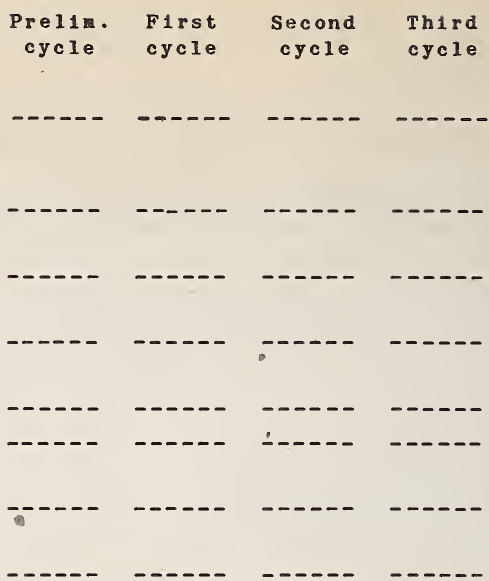

Total for 3 cycles
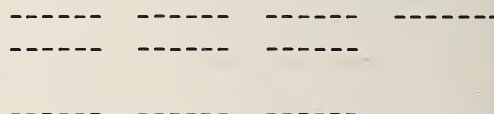

Fan on Fan off

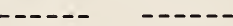

vg for
3 cycles 
Item $25=$ Calorific value of coal (as fired) Btu/lb.

$$
=\frac{100-(\text { ash }+ \text { moisture }) \text { (as fired) }}{100-(\text { ash }+ \text { moisture }) \text { (as recd. })} \times \text { Btu (as recd.). }
$$

Item $26=$ Rate of heat input, Btu/hr.

= Rate of fuel consumption, $1 \mathrm{~b} / \mathrm{hr} \times$ calorific value of coal.

= Item $24 \times 1$ tem 25.

Item $39=$ Static pressure at outlet duct, average, in. water.

NoTE.-Air-outlet duct static-pressure adjustment.

At the start of the preliminary cycle adjust the air damper to produce a static pressure at the air out let duct of $0.20 \mathrm{in}$. water. When pluegas test temperature is attained, readjust air damper as required to bring air outlet duct pressure to 0.20 in. water. Leave damper in this position for the remainder of the tests.

$$
\text { Item } \begin{aligned}
42=\begin{aligned}
\text { Air delivery, } \operatorname{cfm}(\text { standard } \\
\text { condition) }
\end{aligned} & =\frac{\text { Avg wt circulated air (Ib/min) }}{\text { Density of std. air }} \\
& =\frac{\text { Item } 38}{0.075} .
\end{aligned}
$$

NoтE.- Obtain outlet air density in $1 \mathrm{~b} / \mathrm{ft}^{3}$ from figure 2 , volume in cfm at the "obtained" density from figures $2 A$ or $2 B$ and calculate the weight of circulated air in $1 \mathrm{~b} / \mathrm{min}$ as the product of the air volume times its density. Air delivery may be obtained for each cycle, using the average per cycle of outlet air densities and Pitot tube pressure readings, and the values for the three test cycles then averaged, or it may be obtalned by using a three test cycle average of the above mentioned alr densities and Pitot tube pressures.

Under usual conditions of humidity and atmospheric pressure and aside from errors due to setup and recording, the outlet air density taken from figure 2, which does not take into account the variant weights of water vapor in the air or the added air pressure due to the fan, w111 be a close approximation of the true density.

For small variations, not to exceed $5 \mathrm{sq}$ in. in area, from nominal areas of the 9- and 12-in. air-flow-meter throats, air-volune corrections shall be made by multiplying the values obtained from figures $2 A$ or $2 B$ by a correction factor obtained as follows:

$$
\text { 9-1n. throat 12-1n. throat }
$$

Correction factor $=\frac{\text { Actual area }}{\text { Nominal area }}=\frac{\text { actual area, sq. in. }}{63.62}=\frac{\text { actual area, sq. in. }}{113.098}$

Item 43 = Bonnet output (maximum rating), Btu/hr

= Average temperature rise $\times$ air delivery $\times 60 \times 0.018$.

$=$ Item $34 \times 1$ tem $42 \times 1.08$.

Note.-Output may be calculated for each test cycle on the basis of average temperature rise per cycle and the three test cycle results averaged or it may be calculated on the basis of the three test cycle average rise.

Alternately, the average weight of circulated air in $1 \mathrm{~b} / \mathrm{min}$ may be converted to weight in $1 \mathrm{~b} / \mathrm{hr}$ and the bonnet output, for each cycle or for the average of the three test cycles, taken from the curves on figure 3.

Item 45= Radiation and unaccounced-for loss, \%. = Indirect efficiency-direct efficiency = item 47 - item 46. 
Item $46=$ Bonnet efficlency (direct), $\%$.

$$
=\frac{\text { Heat output }}{\text { Heat input }} \times 100=\frac{1 \text { tem } 43}{1 \text { tem } 26} \times 100 \text {. }
$$

Item $\mathbf{4 7}$ = Indirect efficiency, \%.

$$
=100-\text { losses }=100-1 \text { tem } 44
$$

Note. - Loss obtained from figure 4 is taken as the total combustion 1oss. For explanation of the method, see appendix II.

Item $52=$ Minimum rating, Btu/hr.

$=3 \times$ rate of fuel consumption during banking test $\times$ calorific value of coal (as fired) $\times$ direct efficiency $/ 100$.

$=3 \times 1$ tem $50 \times 1$ tem $25 \times \frac{1 \text { tem } 46}{100}$.

Item $55=$ Air velocity through filter $=\frac{\text { Air delivery, cfm }}{\text { Filter area (external dimensions) } \mathrm{ft}^{2}}$

\section{INFORMATIVE LABELING}

7.0. Manufacturer's guarantee.-A manufacturer's guarantee, worded as follows, shall accompany each furnace.

\section{MANUFACTURER'S GUARANTEE}

Solid-Fuel-Burning Forced-Air Furnace.

Catalog Designation.-.---

(Name of manufacturer)

(Address)

This furnace is guaranteed to have an output range from-_._-_maximum rating to.-.-_-minimum rating Btu per hour when tested, without air filters, according to CS109-44 for Solid-Fue1-Burning For ced-Air Furnaces as issued by the United States Department of Commerce. 


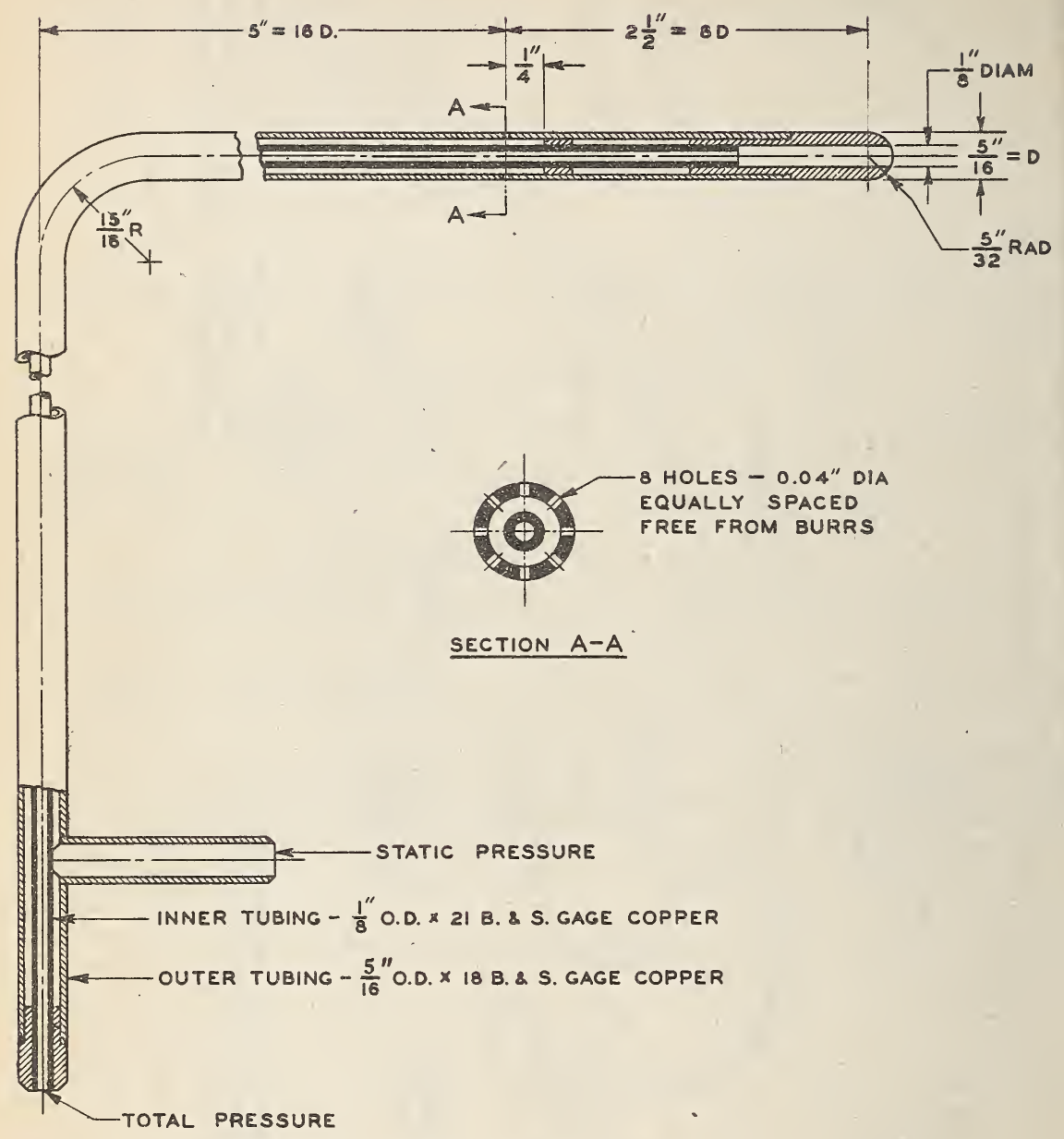

Figure 1. - Pitot tube. 
ATTACHMENT POINT (to $)$ SOFT-SOLDERED, FOR NO. 30 GAGE COPPER WIRE LEADING TO POTENTIOMETER OR SELECTOR SWITCH, EQUAL IN LENGTH TO NO. 30 GAGE CONSTANTAN LEAD WIRE (SEE NOTES I AND 2)

POINTS $\left(t_{1}-t_{12}\right)$ ARE FOR ATTACHMENTS, NO. 30 GAGE CONSTANTAN WIRES (SEE NOTES I AND Z)

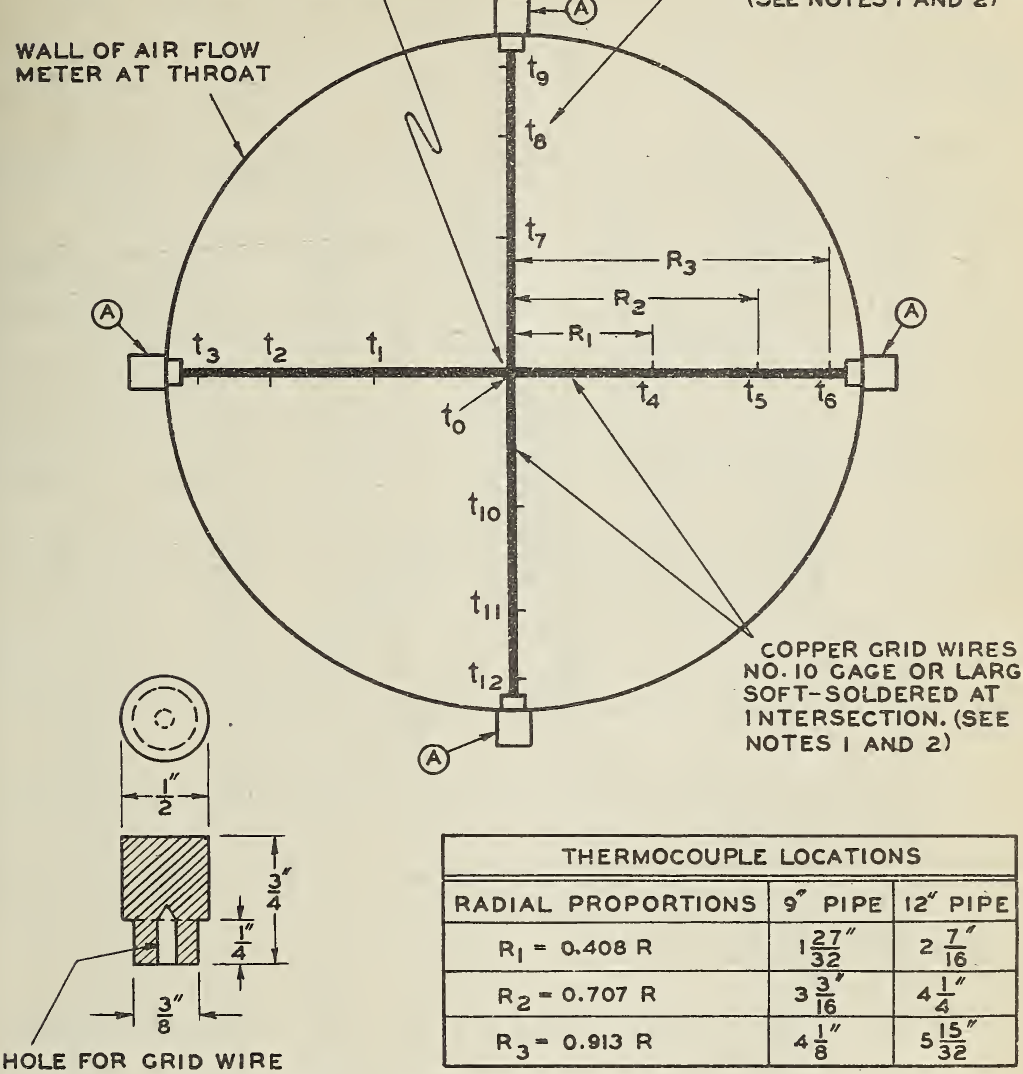

(A) GRID-RETAINING PLUG,-HARDWOOD

FIGURE 1B.- Thermocouple grid for airflow meter.

NOTB 1.- $\left(t_{1}-t_{12}\right)$ No. 30 gege constantan wires of equal length, soft-soldered cold junction of potentioneter.

NOTE 2.-Copper grid wires are bare. All lead wires to grid are electrically insulated their entire length. 


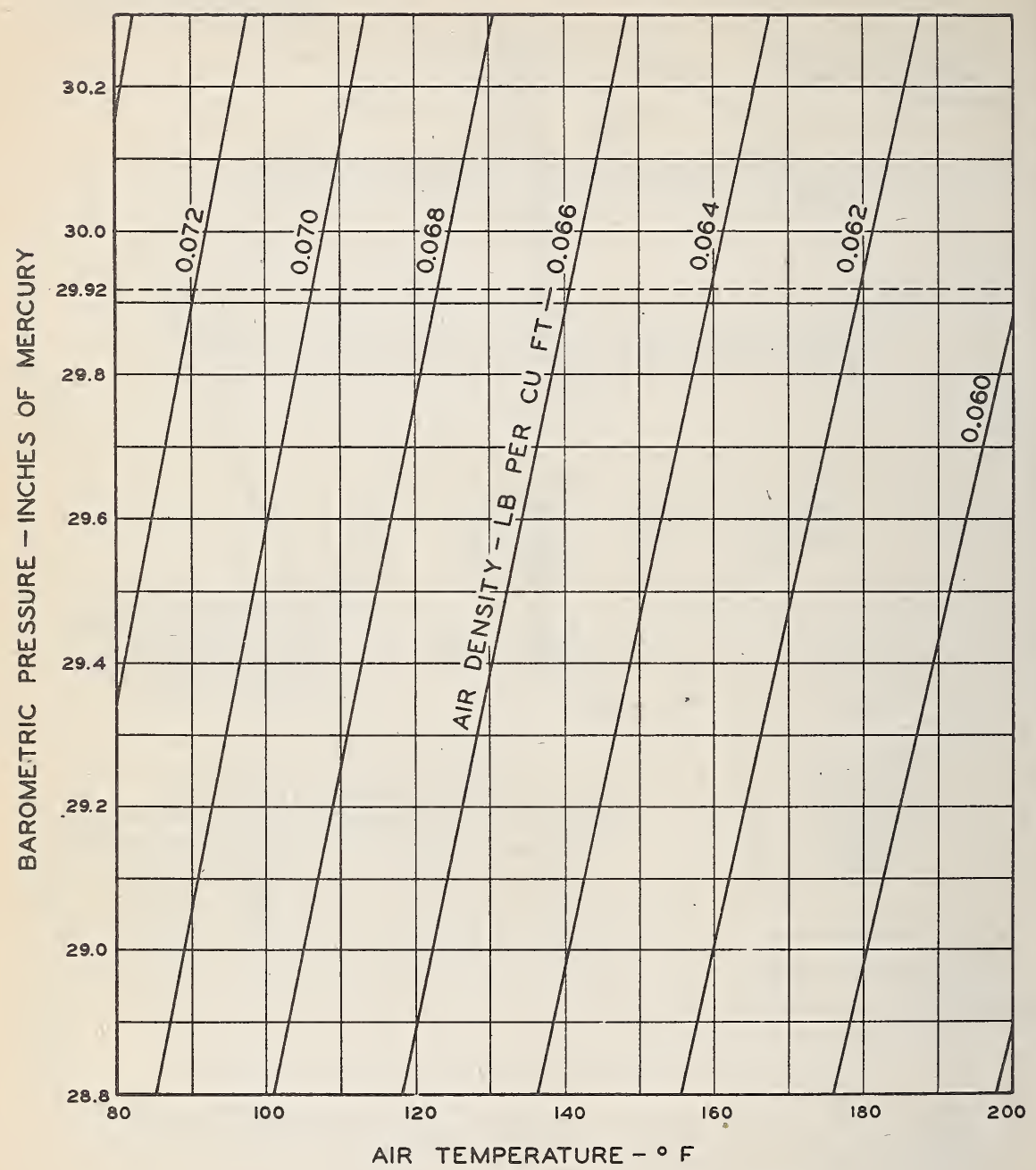

FrGURB 2. $-A$ ir density for dry air $=D=\frac{1.325 B}{460+T}$. 


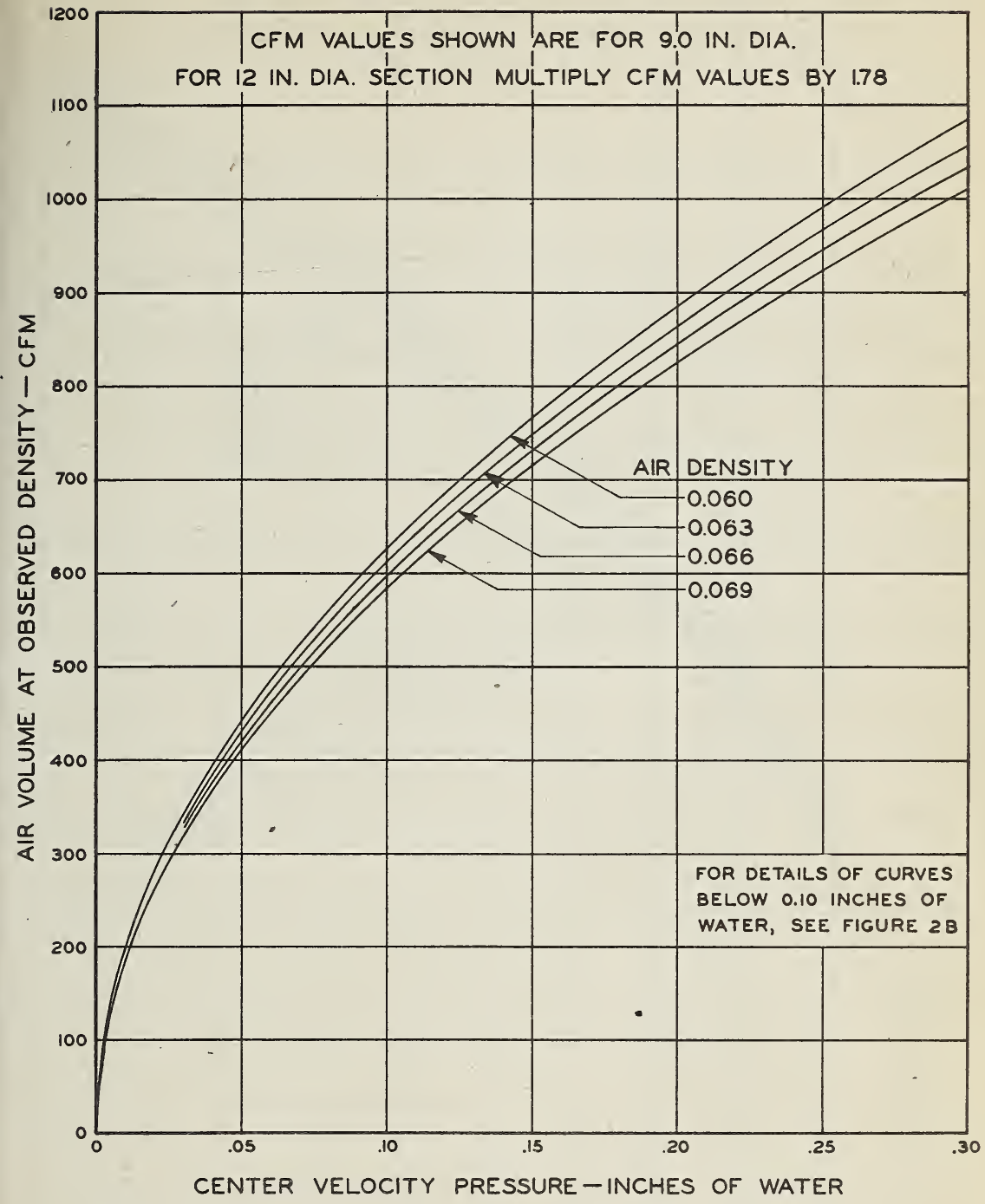

FIGURE 2A.-Calibration curves for 9.0-in.-dian air-flow meter. 


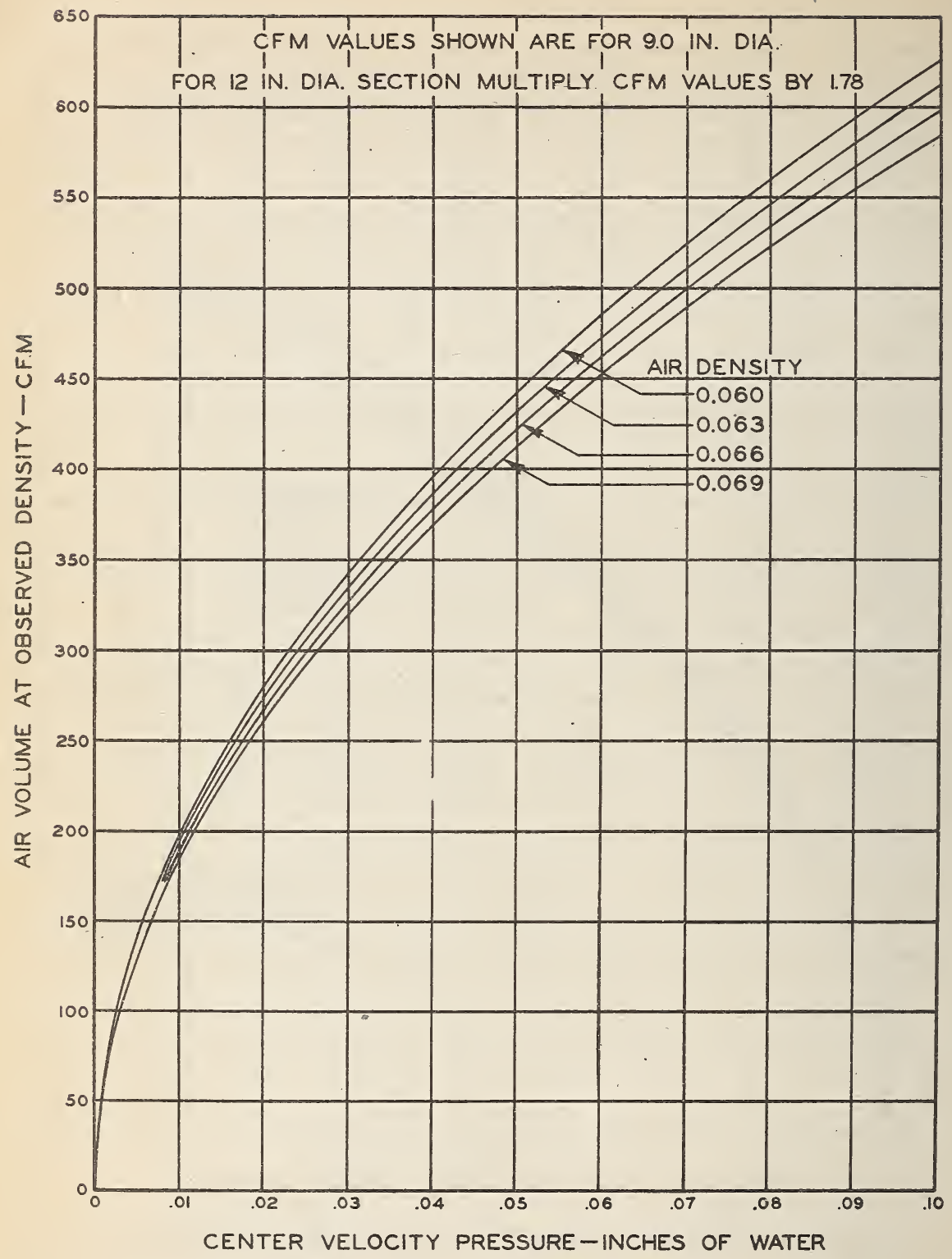

FIGURE 2B.-Calibration curves (detail) for 9.0-in.-diam air-flow meter. 


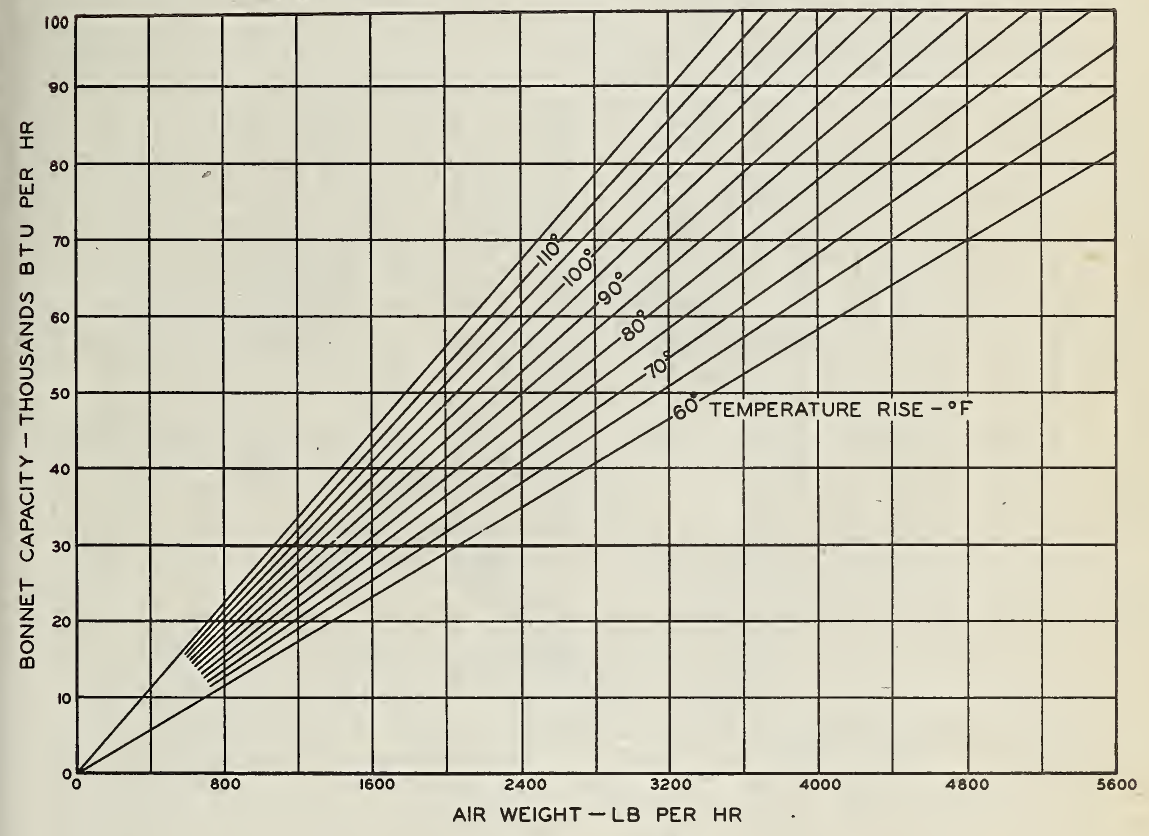

FIGURE 3.-Capacity-air-weight relationships. 


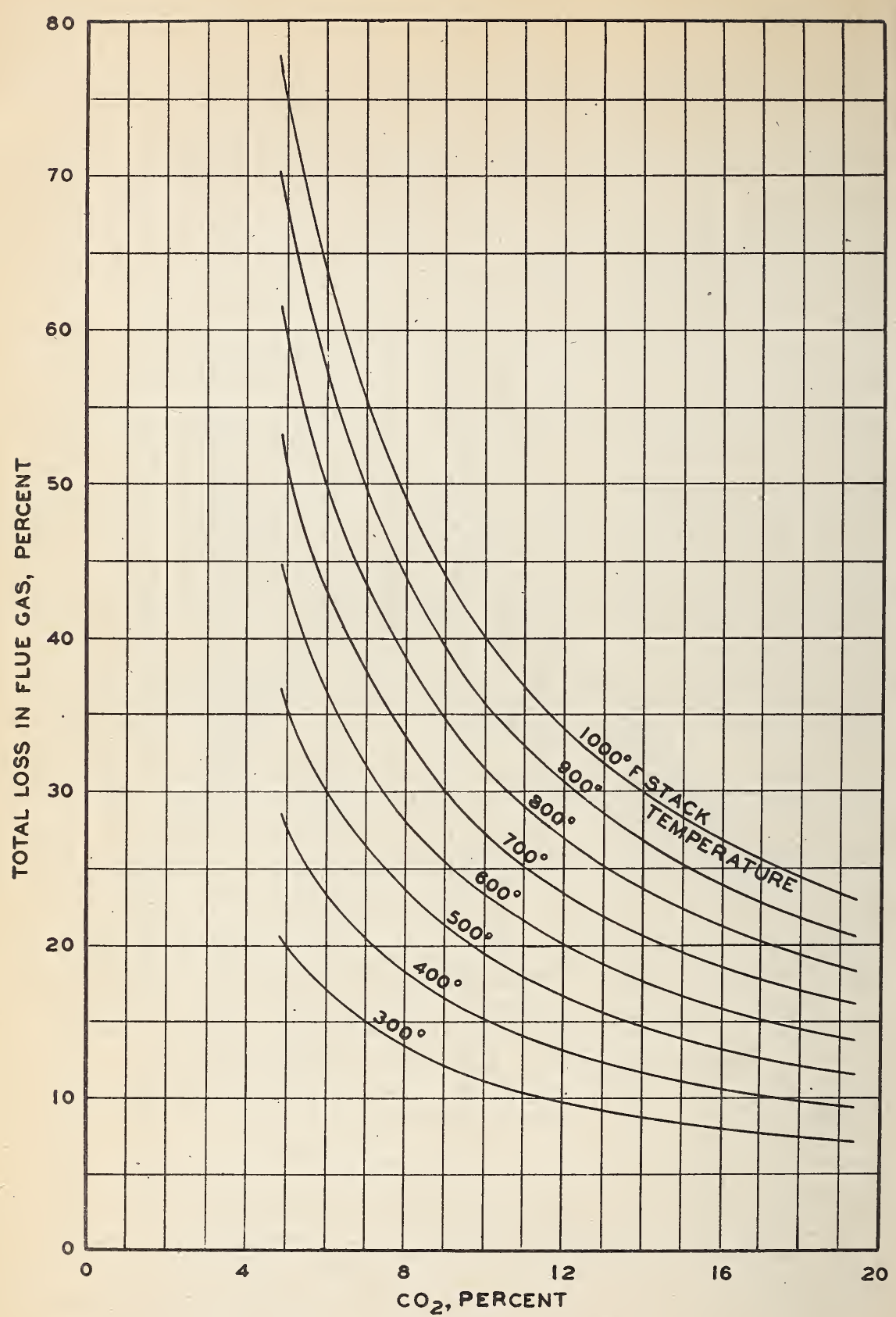

FIGURE 4.-Flue-gas losses with anthracite as fuel. 


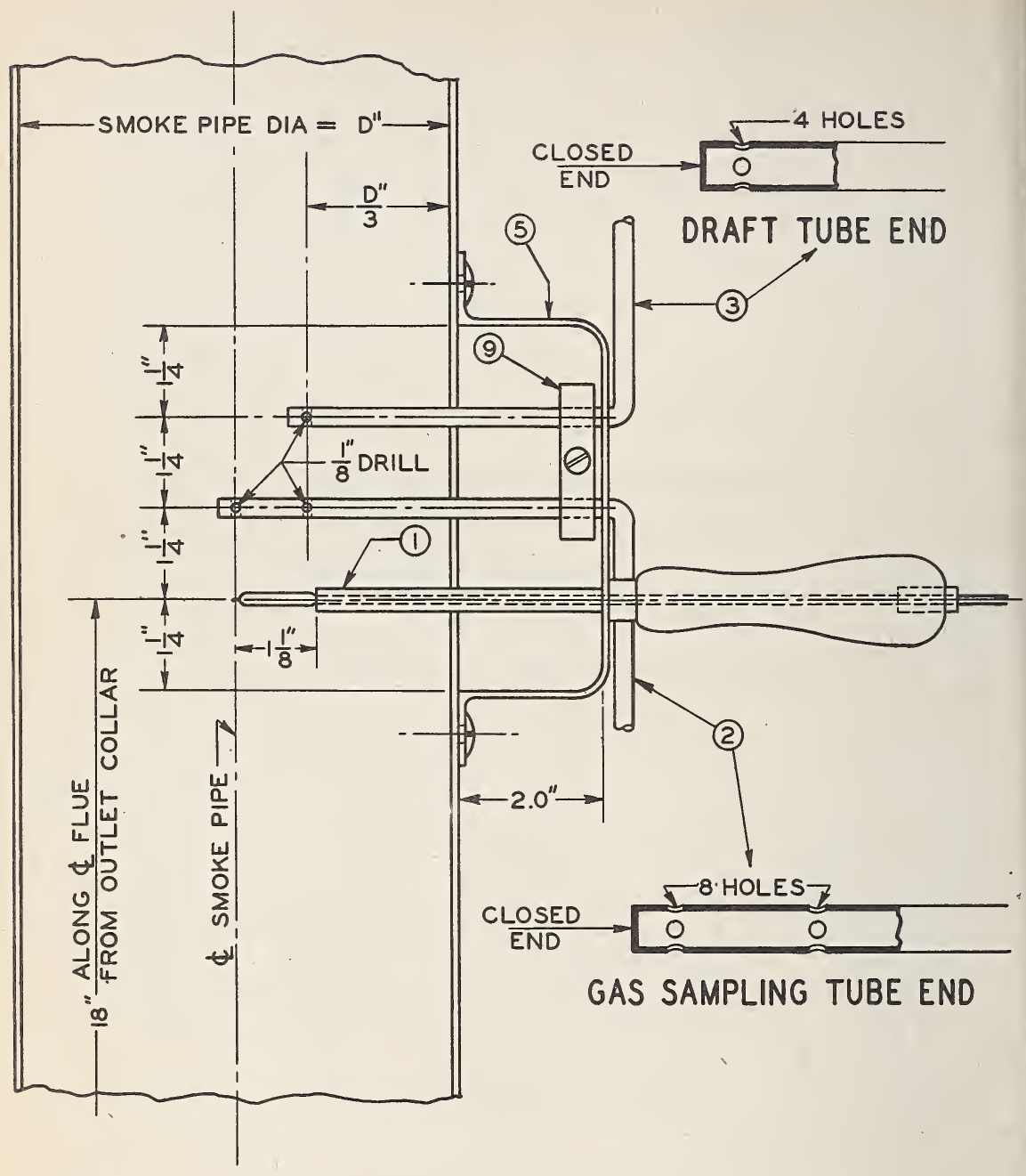

FIGURE 6.-Gas-sampling and draft tubes, thermocouple, and support-bracket assembly.

1, Thermocouple; 2 and 3 , gas-sampling and draft tubes, (1/4-in. by approximately $0.032-1 n$. wal1); 5 and 9 , support brackét and tube clamp, $(1 / 2-1$. by $0.093-$ 1n. half-hard plat steel wire). 

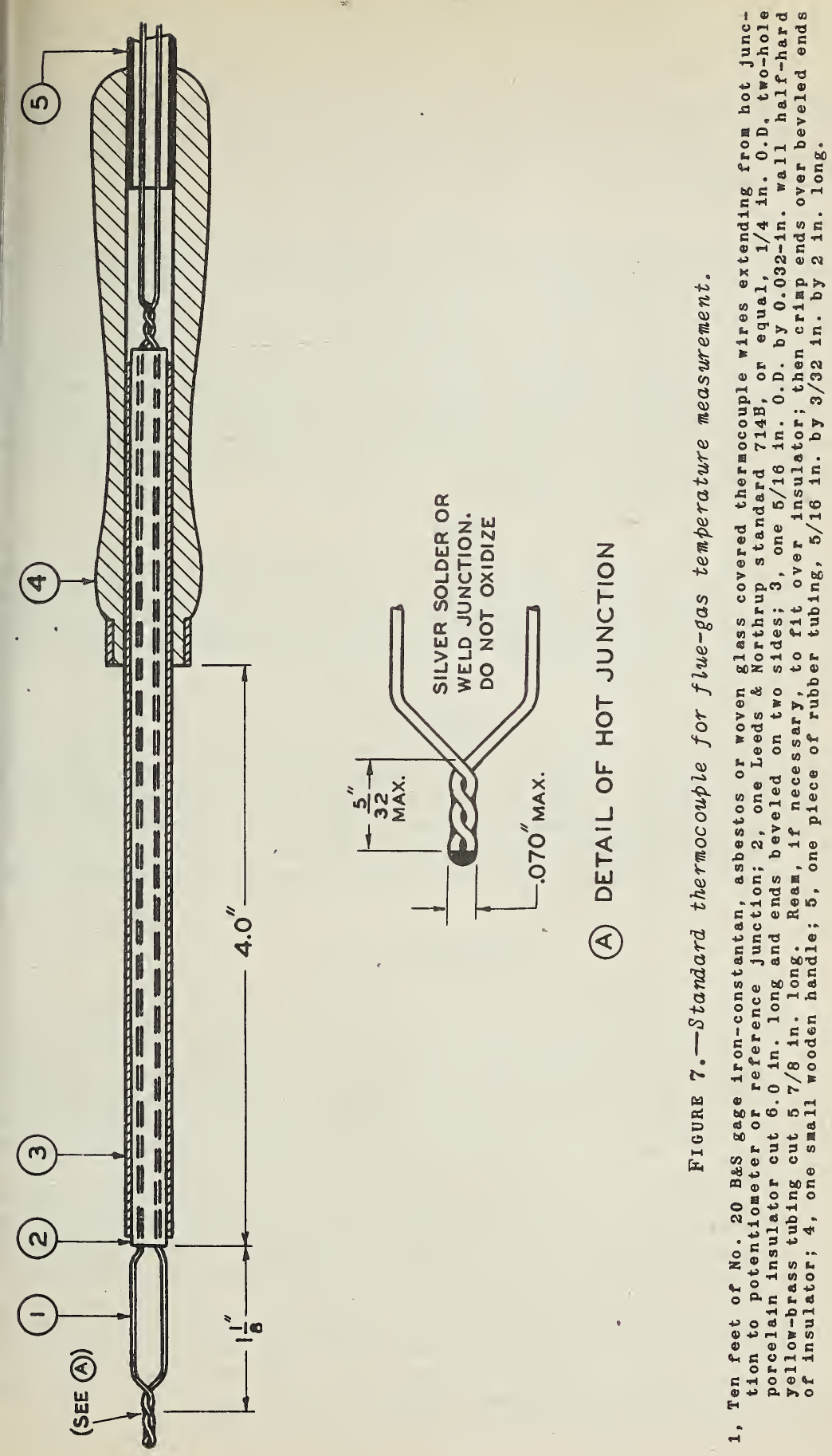


\section{APPENDIX I}

\section{Method of Interpolating Test Results}

When one or more of the varlous $11 \mathrm{mitations}$ set forth in paragraphs 4.10 to 4.15 have been exceeded during a test for maximum output, a second test must be run and the results interpolated as shown by the following examples (refer to fig. 8, p. 29):

\section{CASE A}

Case $A$ is a test on heater No. 1, in which none of the limitations were exceeded. Rated output in this case would be $70,000 \mathrm{Btu} / \mathrm{hr}$.

\section{CASE B}

In the first test on this heater No. 2, the average draft was kept at $0.060 \mathrm{in}$. of water, and the furnace produced $65,000 \mathrm{Btu} / \mathrm{hr}$. However, the maximum permissible stack temperature was exceeded. A second test at $0.040 \mathrm{in}$. of water draft gave $55,000 \mathrm{Btu}$, with none of the limitations exceeded. Straight-line interpolation between the points of these two tests produces a rating of 62,500 .

\section{CASE C}

In the first test on heater No. 3 , it produced $50,000 \mathrm{Btu} / \mathrm{hr}$ at an efficiency of 50 percent. Since this is less than the specified minimum, a second test was conducted at a lower draft. This produced $43,000 \mathrm{Btu} / \mathrm{hr}$ at an efficiency of 58 percent. Interpolation as shown gives a design rating of $46,000 \mathrm{Btu} / \mathrm{hr}$.

\section{CASE D}

The first test on heater No. 4 showed 60 percent efficlency with $40,000 \mathrm{Btu} / \mathrm{hr}$ output. However, the casing temperature was in excess of the $300^{\circ} \mathrm{F}$ specified. A second test at $0.035 \mathrm{draft}$ gave $30,000 \mathrm{Btu} / \mathrm{hr}$ and brought the jacket temperature down to $250 \circ \mathrm{F}$. Interpolation between the two would establish a rating of $33,500 \mathrm{Btu} / \mathrm{hr}$. $700 \mathrm{~F}$.

NoTE. In each case the inlet alr temperature was considered to be

\section{APPENDIX II}

\section{Graphic Method of Determining Flue-Gas Loss}

Curves used for obtaining flue-gas losses are taken from University of Illinols Engineering Experiment Station Circular Series No. 44, Combustion Efficiencies as Related to Performance of Domestic Heating Plants. The curves included in this standard, figure 4, are those obtained for anthracite. The method of calculation described in the circular is as set forth below.

The proximate and ultimate analyses of 54 different coals, ranging from anthracite to lignite, were selected at random from extensive 1 is ts given in publications of the U. S. Bureau of Mines, these lists being reprints from U. S. Bureau of Mines, R. I. 3296, Classification Chart of Typical Coals of the United States.

Using average values obtained from the ultimate analyses, the weights of the dry flue gases in $1 \mathrm{~b} / 1 \mathrm{~b}$ of fuel burned, the molsture formed by combustion, and the molsture contained in the combustion air, were calculated on the basis of complete combustion and for quantities of excess combustion air varying (by steps) from 0 to 300 percent. 


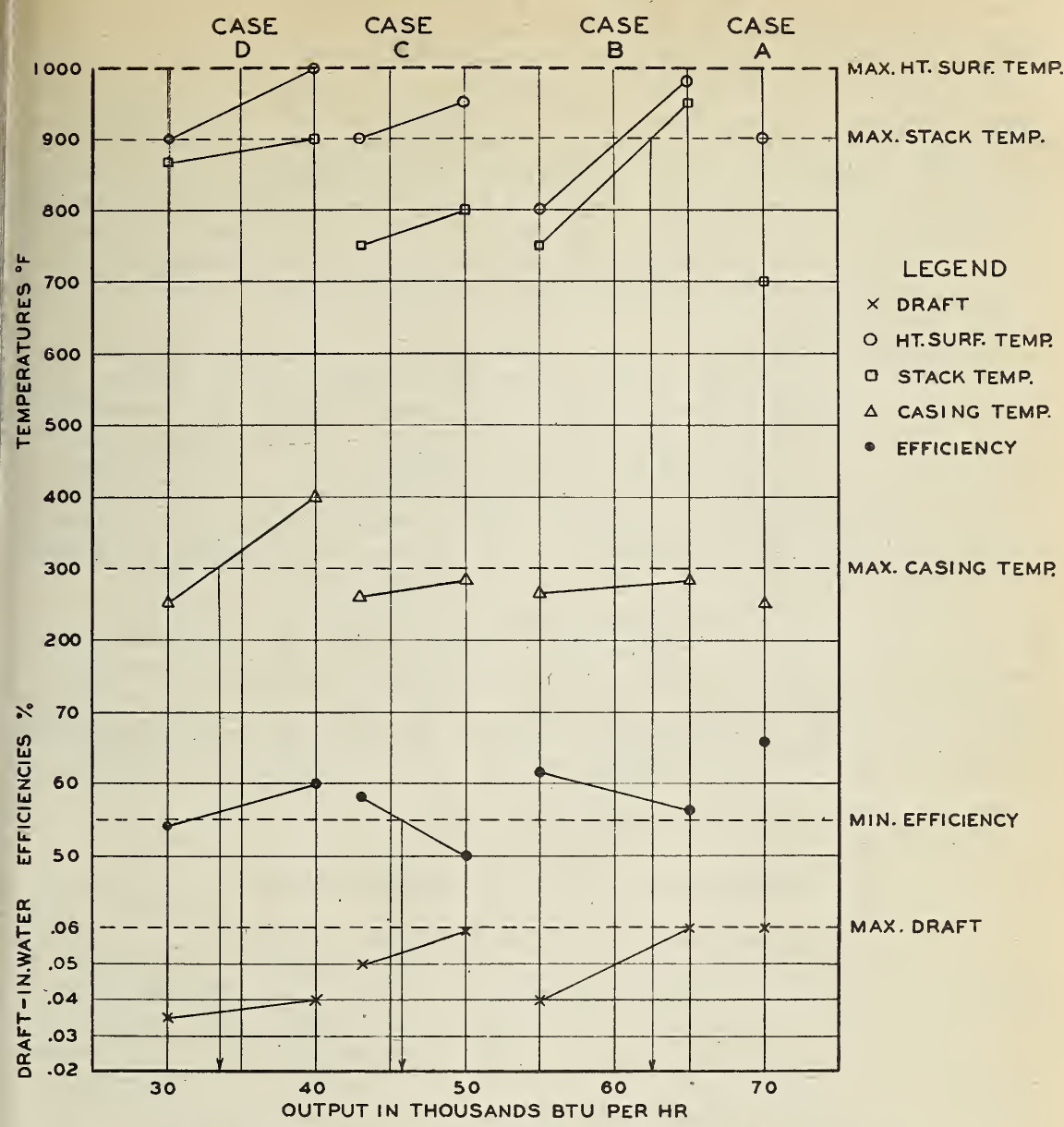

FIOURE 8. Examples of interpolated maximum ratings.

Assuming a temperature of $65^{\circ} \mathrm{F}$ for the combustion air, heat losses in $B t u / 1 b$ of fuel burned were calculated on the basis of mean spectific heats of the dry gases and enthalpy difference in the moisture for the three groups above at flue-gas temperatures varying by steps from 3000 to $1,000^{\circ} \mathrm{F}$. Using the average calorific value in $\mathrm{Btu} / \mathrm{lb}$ of fuel, obtained from the proximate analyses, total flue-gas losses, in percentage of total heat evolved per pound of fuel burned, were obtained as the quotients $(\times 100)$ of the total flue losses, for each percent of excess air and at each temperature, divided by the calorific value.

Using values of $\mathrm{CO}_{3}$, in percentage by volume of dry flue gases, corresponding to percentages by volume of excess air, the curves reproduced in this standard were plotted to show heat loss in percentage of total heat value per pound of fuel burned against percentage by volume of $\mathrm{CO}_{2}$ in stack.

Under the conditions of this determination, losses taken from the curves for varlous values of $\mathrm{CO}_{2}$ are the losses based upon the complete burning of $1 \mathrm{lb}$ of coal, these losses having been converted to percentages of the calorific value of $1 \mathrm{lb}$ of coal. Stack loss, at any given 
value of $\mathrm{CO}_{2}$, due to burning less than the total combustibles in $1 \mathrm{lb}$ of coal, will be less than the value obtained from the curve.

In the case of combustibles remaining in the ash, the stack losses taken from the curves 111 be higher than the actual stack losses, the difference for the sensible loss being approximately in the ratio of weight of carbon per pound of coal from the ultimate analysis to the weight of carbon burned per pound of coal fired. Heat loss in the ash is, therefore, not entirely compensated for but for values of combustible in ash, of 25 percent or less, the values taken from the curves afford a measure of combined ashpit and stack loss within about 2 percent of the correct value.

In the case of unburned or incompletely burned flue gases ( $\mathrm{H}_{2}$ and $\mathrm{C} 0$ ), stack losses, in percent, taken from the curves will be higher than actual stack losses after subtracting the heat value of the combustible gases, approximately in the ratio of the sum of the percentages of $\mathrm{CO}_{2}+\mathrm{CO}+\mathrm{H}_{2}$ to the percentage of $\mathrm{CO}_{2}$. Heat loss due to combustibles in the flue gas is, therefore, not entirely compensated for, but for values of these combustibles, not exceeding about 4 percent of the heating value of the fuel, the values taken from the curves afford a measure of the total stack loss within about $11 / 2$ percent of the correct value.

In general, the stack losses deterinined from the curves are lower than the true losses existing when there are ashpit and incomplete combustion losses. For example, a 4 percent ashpit loss and 3.7 percent incomplete-combustion loss combine to produce an actual indirect efficlency 3.4 percent lower than the curves indicate is the case when the average $\mathrm{CO}_{2}$ is 8 percent and the average stack temperature is $800^{\circ} \mathrm{F}$.

\section{APPENDIX I I I}

\section{Suggested form of $\mathrm{log}$ data sheets}

LOG SHEET FOR SOLID-FUEL-BURNING FORCED-AIR FURNACES

Sheet 1

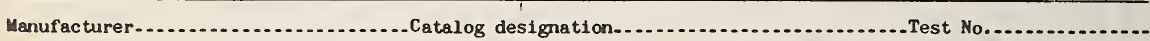
Date............................... Tested by

Barometric pressure.................. in. mercury

Coal used: Kind.

Size..........

Blower speed........................ rpm

Static pressure at outlet duct........... in. mercury

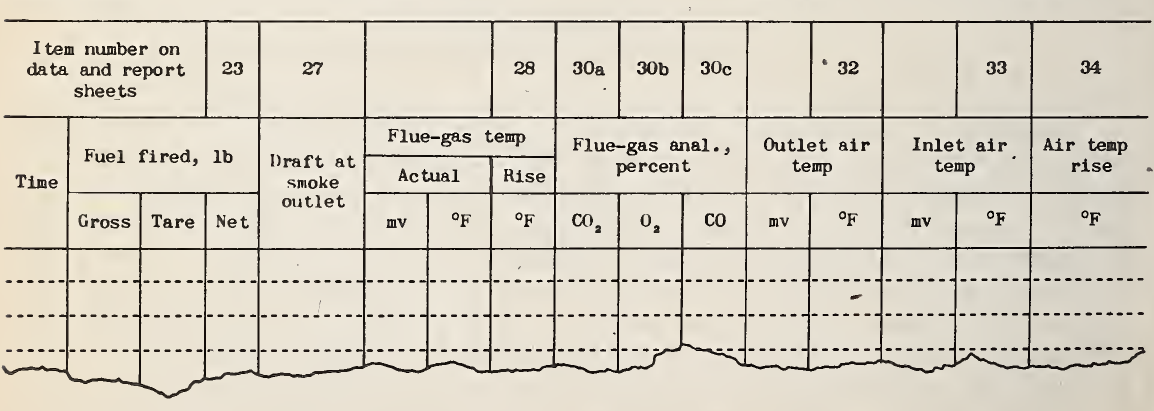


LOG SHEET FOR SิOLID-FUFL-BURNING FORCED-AIR FURNACES

Sheet 2

\begin{tabular}{|c|c|c|c|c|c|c|c|c|c|c|c|c|c|c|}
\hline \multicolumn{2}{|c|}{$\begin{array}{l}\text { Item number on } \\
\text { data and report } \\
\text { sheets }\end{array}$} & \multirow[t]{3}{*}{36} & \multicolumn{6}{|c|}{ Heat-exchanger temperature } & \multicolumn{6}{|c|}{ Jacket temperature } \\
\hline \multirow{2}{*}{ Time } & \multirow{2}{*}{$\begin{array}{l}\text { Velocity } \\
\text { pressure, } \\
\text { in. WG }\end{array}$} & & \multicolumn{2}{|c|}{ Location 1} & \multicolumn{2}{|c|}{ Location 2} & \multicolumn{2}{|c|}{ Location 3} & \multicolumn{2}{|c|}{ Location 1} & \multicolumn{2}{|c|}{ Location 2} & \multicolumn{2}{|c|}{ Location 3} \\
\hline & & & $\mathrm{mv}$ & ${ }^{\circ} \mathrm{F}$ & $\mathrm{mv}$ & ${ }^{\circ} \mathrm{F}$ & $\mathrm{mv}$ & ${ }^{\circ} \mathrm{F}$ & $\mathrm{mv}$ & ${ }^{\circ} \mathrm{F}$ & mv & ${ }^{\circ} \mathrm{F}$ & $\mathbf{m v}$ & ${ }^{\circ} \mathrm{F}$ \\
\hline & & & & & & & & & & & & & & \\
\hline & & & & & & & & & & & & & & \\
\hline & & & & & & & & & & & & & & \\
\hline
\end{tabular}

\section{EFFECTIVE DATE}

8.0. The standard is effective for new production from March 10, 1944.

\section{STANDING COMMITTEE}

9.0. The following individuals comprise the membership of the standing committee, which is to review, prior to circulation for acceptance, revisions proposed to keep the standard abreast of progress. Comment concerning the standard and suggestions for revision may be addressed to any member of the committee or to the Division of Trade Standards, National Bureau of Standards, which acts as secretary for the the committee.

H. WeyBnBerg (chairman) Holland Furnace Co., Holland, Mich.

F. G. SEDGWICK, Waterman-Waterbury Co., Minneapolis, Minn.

A. L. RrвoLt, Rybolt Heater Co., Ashl and, Ohio.

R. E. DALY, American Radiator \& Standard Sanitary Corporation, Fittsburgh, $\mathrm{Pa}$.

V. E. ISENHART, The Lennox Furnace Co., Marshalltown, Iowa.

JонN W. IngOLD, Sears, Roebuck \& Co., Chicago 7, I1l. (representing Mail Order Association of America).

E. E. Roberts, Roberts-Hamil ton Co., 709 S. 3d St., Minneapolis 15, Minn. (representing Central Supply Association).

Willard A. Neis, The Ne is Co., 7943 W. National Ave., West Allis, Wis. (representing Heating, Piping \& Alr Conditioning Contractors National Association).

J. HaRVEY MANny, Robinson Furnace Co., 4600 W. Monroe St., Chicago, Ill. (representing Sheet Metal Contractors National Association, Inc.). Associated General Contractors of America, Inc. (Invited to name a representative).

R. K. ThulMaN, Federal Housing Administration, Washington 25, D. C.

F. A. Рескнам, Office, Chief of Engineers, War Department, Washington 25, D. C.

WALTER B. RUEVE, 600 Sunset Road, Louisville 6, Ky. (representing American Institute of Architects).

Henry T. Coates, Dairymen's League Co-0p. Assn., Inc., 11 West 42nd St., New York 18, N. Y. (representing National As sociation of Purchasing Agents). 
Hugh E. KeELer, 231 West Engineering Bldg., University of Michigan, Ann Arbor, Mich. (representing American Institute of Consulting Engineers). R. C. Johnson, Anthracite Industries, Inc., Primos, Delaware County, Pa.

S. KoNzo, University of Illinois, Urbana, Ill.

B. A. LANDRT, Battelle Memorial Institute, Columbus 1, Ohio.

C. C. Wrigut, Pennsylvania State College, State College, Pa.

R. S. DILL, Heat Transfer Section, National Bureau of Standards, Washington 25, D. C.

\section{HISTORY OF PROJECT}

10.0. As a result of informal conferences on April 3 and 14, 1942, between representatives of Anthracite Industries Laboratory and interested Government agencies, and following a specific request of April 20, 1942, from the Federal Housing Administration, there was developed by the industry in cooperation with Government agencies, a proposed commercial standard for solid-fuel-burning furnaces.

10.1. Conferences of interested individuals were held at the National Bureau of Standards on June 23, 1942, and October 15, 1942, as a result of which a second draft of the proposed standard was circulated November 11 and 12, 1942, to the industry for comment.

10.2. A special conference, held in Washington on February 22 and 23, 1943, revised the proposed standard in the light of comment, and this draft was circulated for further comment on May 15, 1943. Following subsequent adjustments to suit this comment, especially that of the National Warm Air Heating and Air Conditioning Association, a revised draft was circulated on August 16, 1943, to the entire trade for written acceptance, as there appeared to be no objections requiring adjustment at a general conference.

10.3. Following acceptance by a satisfactory majority, in the absence of active opposition, an announcement was issued on November 10, 1943, that the standard had been accepted as the recorded voluntary standard of the trade, effective for new production from March 10, 1944. 


\section{ACCEPTANCE OF COMMERCIAL STANDARD}

If acceptance has not previously been filed, this sheet properly filled in, signed and returned, will provide for the recording of your organization as an acceptor of this commercial standard.

\section{Date}

Division of Trade Standards, National Bureau of Standards, Washingt on, D. C.

Gent lemen:

Having considered the statements on the reverse side of this sheet, we accept the Commercial Standard CS109-44 as our standard of practice in the

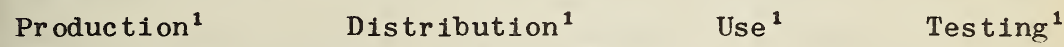

of solid-fuel-burning forced-air furnaces.

We will assist in securing its general recognition and use, and will cooperate, with the standing committee to effect revisions of the standard when necessary.

Signature of individual officer

Name and title of above officer

Organization (Fili in exactly as 1 t should be listed)

Street address

C1ty and State

1 Please designate which group you represent by draing lines through the other three. Please flle separate acceptances for all subsidiary conpantes and afflliates which should be listed separately as acceptors. In the case of related interests, trade papers, colleges, etc., desiring to record their general approval, the words "In principle" should be added after the signature. 


\section{TO THE ACCEPTOR}

The following statements answer the usual questions arising in connection with the acceptance and its significance:

1. Enforcement.-Commercial standards are commodity specifications voluntarily established by mutual consent of those concerned. They present a common basis of understanding between the producer, distributor, and consumer and should not be confused with any plan of governmental regulation or control. The United States Department of Commerce has no regulatory power in the enforcement of their. provisions, but since they represent the will of the interested groups as a whole, their provisions through usage soon become established as trade customs and are made effective through incorporation into sales contracts by means of labels, invoices and the $11 \mathrm{ke}$.

2. The acceptor's responsibility. - The purpose of commercial standards is to establish for specific commodities, nationally recognized grades or consumer criteria and the benefits therefrom will be measurable in direct proportion to their general recognition and actual use. Instances will occur when it may be necessary to deviate from the standard and the signing of an acceptance does not preclude such departures; however, such signature indicates an intention to follow the commercial standard where practicable, in the production, distribution, or consumption of the article in question.

3. The Department's responsibility.- The major function performed by the Department of Commerce in the voluntary establishment of commercial standards on a Nation-wide basis is fourfold: first, to act as an unbiased coordinator to bring all interested parties together for the mutually satisfactory adjustment of trade standards; second, to supply such assistance and advice as past experience with similar programs may suggest; third, to canvass and record the extent of acceptance and adherence to the standard on the part of producers, distributors, and users; and fourth, after acceptance, to publish and promulgate the standard for the information and guidance of buyers and sellers of the commodity.

4. Announcement and promulgation.- When the standard has been endorsed by a satisfactory majority of production or consumption in the absence of active, valid opposition, the success of the project is announced. If, however, in the opinion of the standing committee or the Department of Commerce, the support of any standard is inadequate, the right is reserved to withhold promulgation and publication. 


\section{ACCEPTORS}

11.0. The organizations and individuals listed below have accepted this standard as their standard of practice in the production, distribution, and use of solid-fuel-burning forced-air furnaces. Such endorsement does not signify that they may not find it necessary to deviate from the standard, nor that producers so listed guarantee all of their products in this field to conform with the requirements of this standard. Therefore, specific evidence of conformity should be obtained where required.

\section{ASSOCI ATIONS}

American Association of Engineers, Chicago, Ill. American Specification Institute, Chicago, Ill. Associated General Contractors of America, Inc., 'The, Washington, D. C.

Central Supply Association, Chicago, I1l.

Dairymen's League Co-operative Association, Inc., New York, N. Y.

Heating \& Piping Contractors District of Columbia Association, Inc., Washington, D.C. (In principle.) National Association of Purchasing Agents, New York, N. $\mathrm{Y}$.

National Council of Women of the U. S., Inc., New York, N. Y.

National Warm Air Heating \& Air Conditioning Association, Cleveland, Ohio. (In principle.)

Producers Council, Inc., The, Washington, D. C. (In principle.)

Southern Supply \& Machinery Distributors' Association, Inc., Atlanta, Ga.

Southern Wholesalers Association, Atlanta, Ga.

Steam Heating Equipment Manufacturers Association, New York, N. Y. (In principle.)

Narm Air Furnace Manufacturers Council, Cleveland, Ohio.

\section{FIRMS}

Almirall \& Co., Inc., New York, N. Y.

American Furnace Co., St. Louis, Mo.

American Furnace \& Foundry Co., The, Milan, Mich.

American Houses, Inc., New York, N. Y.

Arms trong Furnace Co., Columbus, Ohio.

Baltimore, City of, Bureau of Plans \& Surveys, Baltimore, Md.

Battelle Memorial Institute as Acting Research Iaboratory for Bituminous Coal Research, Inc., Columbus' Ohio.

Bovee Furnace Works, Waterloo, Iowa.

Bowser Morner Testing Iaboratories, Dayton, Ohio.

California Testing Laboratories, Inc., Los Angeles, Calif.

Case School of Applied Science, Cleveland, Ohio.

Central Co-operative Wholesale, Sunerior, Wis.

Chaney Hardware, Montpelier, Ind.

Chrysler Corporation, Airtemp Division, Dayton, Ohio

Cincinnati, City of, Department of Purchasing, Cincinnati, Ohio.

Cleveland Heater Co., Air Controls, Inc., Division, Cleveland, Ohio.

Cleveland Steel Products Corporation, Cleveland, Ohio.

Coal-Heat (Magazine), Chicago, I1l. (In principle.) Colladay Wholesale Hardware Co., The Frank, Hutchinson, Kans.

Consolidated Coal Co., Chicago, I1l.

Conwell \& Co., E. L., Philadelphia, Pa

Co-op. Community Builters, Inc., Wauwa tosa, Wis.

Coroaire Heater Cornoration, The, Cleveland, ohio.

Corriveaux, F. - Home \& Industrial Service, Schenectady, N. Y.

Dajlman Supply Co., Sacramențo, Calif.

Detroit Testing Laboratory, The, Detroit, Mich.

Enterprise Foundry Co., Inc., Rochester, N. Y.

Excelsior Steel Furnace Co., The, Chicago, Ill.

Farquhar Furnace Co., The, Wilmington, Onio.

Fitzgibbons Boiler Co., Inc., New York, N. Y.

Forest City Foundries Co., The, Cleveland, Ohio.

Foster-Thornburg Hardware Co., Huntington, W. Va.
Froehling \& Robertson, Inc., Richmond, Va

Front Rank Furnace Co., St. Louis, Mo. (In principle.) Gardner Hardware Co., Minneapolis, Minn.

Hall-Neal Furnace Co., Indianapolis, Ind.

Hanks, Inc., Abbot A., San Francisco, Calif.

Harrington \& Associates, Joseph, Chicago, Ill.

Henkle \& Joyce Hardware Co., Lincoln, Nebr.

Herlan-Patterson, Inc., Buffalo, N. Y.

Holland Furnace Co., Holland, Mich.

Home Furnace Co., Holland, Mich.

International Heater Co., Utica, N. Y.

Iowa, University of, Iowa City, Iowa.

Kalamazoo Stove \& Furnace Co., Kalamazoo, Mich.

Kol-Master Corporation, Oregon, Ill

Iarson Hardware Co., Sioux Falls, S. Dak.

Lau Blower Co., The, Dayton, Ohio.

Lennox Furnace Co., Columbus, Ohio, and Marshall town, Iowa.

Iennox Furnace Co., Inc., The, Syracuse, N. Y.

Najestic Co., The, Huntington, Ind.

Marshall Furnace Co., Marshall, Mich.

Martino Co., A. R., Waterbury, Conn.

Master Plumber \& Heating Contractor, The, Brooklyn,

N. Y.

May-Fiebeger Co., The, Newark, Ohio.

McGow in Lyons Hardware \& Supply Co., Mobile, Ala.

McMahill Heating Service, Omaha, Nebr.

Mellish \& Murray Co., Chicago, Ill.

Meyer Furnace Co., The Peoria, I11.

Michigan Tank \& Furnace Corporation, Detroit, Mich. Midland Cooperative Wholesale, Minneapolis, Minn.

Minnesota Testing Laboratories, Inc., Duluth, Minn.

Modern Installation Co., Prospect Park, Paterson, N. J.

Morrisdale Coal Mining Co., The, New York, N. Y. sueller Furnace Co., L. J., Milwaukee, Wis.

Nebraska, University of, Mechanical Engineering Denartment, Lincoln, Nebr.

New England Coal \& Coke Co., Boston, Mass. (In principle.)

New Or leans, Inc., Better Business Bureau of, New Orleans, La. (In principle.)

New York Coal Sales Co., Columbus, Ohio.

New York Testing Laboratories, Inc:, New York, N. Y. Newark College of Engineering, Newark, N. J

North American Coal Corporation, The, Cleveland, Ohio.

North Carolina State College of Agriculture \& Engineering of the University of North Carolina, Raleigh, N. C.

Northern Controlled Heat Co., Inc., Watertown, N. Y. Vorthwest Stove \& Furnace Works, Inc., Portland, Oreg. Northwestern Hanna Fuel Co., st. Paul, Minn.

Notre Dame, University of, Testing Laboratory, Notre Dame, Ind.

$0^{\prime H a}$ ir '\& Co., P. E., San Francisco, Callif

Olsen Manufacturing Co., The C. A., Elyriz, Uhio.

Patzig Testing laboratories, Des Moines, Iowa.

Pennsylvania State College, The, State College, Pa. (In principle.)

Philadel phia \& Reading Coal \& Ir on Co., Philadelphia, $\mathrm{Pa}$

Plumbing \& Heating Selling Co., New Orleans, La

Premier Furnace Co., Dowagiac, Mich.

Purdue University, Iafayette, Ind.

Rearick Bros. Automatic Heating, Gary, Ind.

Richmond Hardware Co., Richmond, Va.

Roberts-llamilton Co., Minneapolis, Minn.

Rose Polytechnic Institute, Ferre Haute, Ind.

Round Oak Co., Dowagiac, Mich. 
Ruly Hurnace Co., Dowagiac, Mich.

Rybolt Heater Co., Ashiand, Ohio.

Sacramento, Better Business Bureall of, Sacramento, Callf. (In principle.)

st. Louis Furnace Manufacturing Co., St. Louis, Mo. st. Louis Sampling \& Testing Works, St. Louis, Mo. Scranton Better Business Bureau, Scranton, Pa. (In principle.)

Sears, Robuck \& Co., Chicago, Ill.

Swarthmore Heating Service, Swarthmore, Pa.

Tha tcher Furnace Co., Garwood, N. J.

Twining Laboratories, The, Fresno, Calif.

U.S. Air Conditioning Corporation, Minnea molis, Minn.

Viking Air Conditioning Corporation, Cleveland, Ohio.

Viking Manufacturing Corporation, The, Dayton, Ohio. Ward, Inc., Thomas E., Hanover, N. H.

Washington, University of, Seattle, Wash.
Wa terman-*a terbury Co., The, Minneapolis, Minn. Waverly lieating Supply Co., Boston, Mass.

Wes tern Furnaces, Inc., Tacoma, Wash.

Westwick \& Son., John, Galena, IIl.

williamson Heater Co.. The, Cincinnati, Ohio.

Wise Furnace Co., The, Akron, Uhio.

Wyeth Hardware \& Manufacturing $C_{0}$. , St. Joseph, Mo.

\section{U. S. GOVERNMENT}

Agriculture, U. S. Department of, Washington, D. C. Federal Works Agency, Public Buildings Administrqtion, Washington, D. C. (In principle.)

Interior, Department of the, Office of Indian Affairs, Construction Division, Chicago, Ill.

Navy Department, Bureau of Yards \& Docks, Nashington, D. C. 